\title{
The Role of $\gamma \delta$ T Cells in Fibrotic Diseases
}

\author{
Ilan Bank, M.D.* \\ Department of Medicine, Maayenei Hayeshuah Medical Center, Bnei Brak, Israel; Rheumatology Unit, \\ Autoimmunity Institute and L aboratory of Immunoregulation, Sheb a Medical Center, Ramat Gan, Israel; \\ and Sackler School of Medicine, Tel Aviv University, Tel Aviv, Israel
}

\begin{abstract}
ABST RACT
Inflammation induced by toxins, micro-organisms, or autoimmunity may result in pathogenic fibrosis, leading to long-term tissue dysfunction, morbidity, and mortality. Immune cells play a role in both induction and resolution of fibrosis. $\gamma \delta \mathrm{T}$ cells are an important group of unconventional T cells characterized by their expression of non-major histocompatibility complex restricted clonoty pic T cell receptors for non-peptide antigens. Accumulating evidence suggests that subsets of $\gamma \delta \mathrm{T}$ cells in experimentally induced fibrosis following bleo mycin treatment, or infection with Bacillus subtilis, play proinflammatory roles that instigate fibrosis, whereas the same cells may also play a role in resolving fibrosis. These processes appear to be linked at least in part to the cytokines produced by the cells at various stages, with interleukin (IL)-17 playing a central role in the inflammatory phase driving fibrosis, butlater secretion of IL-22, interferon $\gamma$, and CXCL1o preventing pathologic fibrosis. Moreover, $\gamma \delta$ T cells appear to be involved, in an antigen-driven manner, in the prototypic human fibrotic disease, systemic sclerosis (SSc). In this paper we review in brief the scientific publications that have implicated $\gamma \delta$ T cells in fibrotic diseases and their pro- and anti-fibrotic effects.
\end{abstract}

KEY WORDS: Fibrosis, systemic sclerosis, $\gamma \delta$ T cells

\begin{abstract}
Abbreviations: AhR, a ryl hydrocarbon receptor; BAL, bronchoalveolar lavage; BLM, bleomycin; CCL, chemokine lig and; CXCL, chemokine C-X-C ligand; FPP, farnesyl py rophosphate; IL, interleukin; IPP, isopentenyl py rophosphate; KO, kn ockout; MHC, major histocom patibility; NKT, natural killer T; PBMC, peripheral blood mononuclear cells; r, receptor; SSc, sy stem ic sclerosis; TCR, T cell receptor; UCD-200, University of Ca lifornia at Davisline 200; V, variable.

Cit ation: Bank I. The Role of $\gamma \delta$ T Cells in Fibrotic Diseases. Rambam Maimonides Med J 2 016;7 (4):eoo29. doi:10.5041/RMMJ.10256 Review

Copy right: (C) 2016 Bank. This is an open-access article. All its content, except where otherwise noted, is distributed u n der the terms of the Creative Com mons Attribution License (http://creativecom mons.org/licenses/by/3.o), which per mits unrestricted use, distribution, and r eproduction in a ny m edium, provided the original w ork is properly cited.
\end{abstract}

Conflict of interest: No potential conflict of in terest relevant to this article was reported.

*E-mail: ibank@post.tau.ac.il or ilanb@mhmc.co.il 


\section{INT RODUCTION}

Extensivetissue deposition of extracellular matrix proteins by activated fibroblasts may lead to structural and functional tissue damage. Uncontrolled fibrosis may be a consequence of inflammation triggered by pathogens, autoimmunity or malignancies, and is related to dysregulation of multipletypes of immune cells including subsets of T cells. ${ }^{1} \gamma \delta \mathrm{T}$ cells, a "non-conventional" $\mathrm{T}$ cell population, were discovered in 1986 and, in contrast to "conventional” $T$ cells expressing the $\alpha \beta$ T cell receptor (TCR), recognize non-peptidic antigens independent of major histocompatibility (MHC) molecules. ${ }^{2-5}$ In humans there are two major subsets; the first expresses TCR $\gamma \delta$ That use variable $(\mathrm{V})$ region genes $\mathrm{V} \gamma 9$ and $\mathrm{V} \delta 2$ in the $\gamma$ and $\delta$ TCR polypeptides, respectively. Vү $9 \delta 2$ TCR sense low-molecularweight phosphoantigens of microbes, and host cellproduced phosphoantigens in the mevalonate pathway. ${ }^{6}$ These phosphoantigens bind to the extra- or intracellular domains of the cell surface membrane molecule butyrophilin 3A1 (CD277), inducing a novel structure or conformation that is detected by cells expressing the $\mathrm{V} \gamma_{9} \delta 2 \mathrm{TCR}$, triggering their cy tokine production and/or cyto toxicity 7,8 Thus, $\mathrm{V} \gamma 9 \delta 2 \gamma \delta$ T cells are poised to detect and respond to infections or altered intracellular metabolism induced, for example, by intracellular infections, or a malignant transformation. The second human $\gamma \delta \mathrm{T}$ cell subset is characterized by the V $\delta 1$ genes in the $\delta$ TCR polypeptide. $V \delta 1^{+} \gamma \delta$ T cells are distributed along epithelial barriers. Their TCR detects lipid antigens presented by CD1 molecules, similar to natural killer T (NKT) cells.9,10 Although the murine immune sy stem lacks phosphoantigen-reactive $\delta \mathrm{T}$ cells, the role of butyrophilins in $\gamma \delta \mathrm{T}$ cell development is retained in mice, at least for some subsets, as ex emplified by the dependence of entire subsets of murine $\gamma \delta \mathrm{T}$ cells on specific buty rophilins for their development and homing to the skin and gut.11-13 Readers are referred to comprehensive reviews of murine $\gamma \delta$ T cells by Vantourout and Hay day.4,5

Despite obvious distinctions between themurine and human $\gamma \delta$ T cells, there is ample evidence to indicate that the functional repertoire of $\gamma \delta \mathrm{T}$ cells in both humans and mice includes cytokine production, cytotoxicity, and help for B cells. 4 Uniquely, moreover, subsets of these cells acquire their full functional potential during maturation in the thy mus, contrasting with $\alpha \beta$ T cells that fully mature functionally only after encountering antigens in the peripheral lymphatic system. In this regard, in both humans and mice, $\gamma \delta$ T cells are similar to innate lymphocytes, which positions them at the forefront of the response to foreign invaders and internal "stress" conditions, including, for ex ample, metabolic aberrations induced by malignancy, infections or other stressogens. 4 Indeed, inflammatory, malignant, and infectious conditions are associated with numerical alterations of $\gamma \delta$ T cells in humans. ${ }^{14}$ Given their unique abilities to detect non-peptide antigens, that may evade adaptive $\alpha \beta$ T cells, and their rapid, non-MHC-dependent responsiveness, these cells may thus play a critical and uniquerole in diseases. Here, we review the involvement of the $\gamma \delta$ $\mathrm{T}$ cell subset in pathological fibrotic responses. Specifically, we concentrate on systemic sclerosis (SSc), the prototypic systemic fibrosing disease in humans, and on animal models in experimental settings mimicking SSc, as well as in organ-localized pulmonary and liver fibrosis.

\section{Y $\delta$ T CELLSIN HUMAN FIBROSIS}

Most of the evidence linking human $\gamma \delta$ T cells to fibro sis comes from studies of the systemic sclerosis (SSc). Thus, in SSc , $\mathrm{V} \delta 1^{+} \gamma \delta \mathrm{T}$ cells were identified in the skin during very early stages of SSc. ${ }^{15}$ Furthermore, the div ersity of $\mathrm{V} \delta 1$ junctional regions (composed of the variable [V], diversity [D], and joining $[\mathrm{J}]$ gene segments) in peripheral blood (PB) mononuclear cells (PBMC), lung, esophagus, stomach, or skin of patients was limited in SSc patients, and the same V $\delta 1-J \delta$ junctional sequences could be isolated from multiple tissues suggesting an antigen-driven expansion of $\mathrm{V} \delta 1^{+} \gamma \delta \mathrm{T}$ cells in SSc. ${ }^{16}$ In a large group of patients, percentages of $\mathrm{PB} \gamma \delta \mathrm{T}$ cells were significantly lower in SSc patients with diffuse and late-stage disease with pulmonary involvement, muscle involvement, and the presence of anti-Scl-7o antibodies, mimicking the University of Californiaat Davis line (UCD)-200 chicken model described below. ${ }^{17}$ In addition, $\mathrm{V} \gamma 9^{+} \gamma \delta$ T cells persist in SSc patients' $\mathrm{PB}$, respond by expression of CD25 and CD69 to a phosphoantigen, isopentenyl pyrophosphate (IPP), and induce contact-dependent, tumor necrosis factor (TNF) $\alpha$-independent apoptosis of cultured sy novial fibroblasts. ${ }^{18}$ However, higher concentrations of zoledronate, an aminobisphosphonate that increases IPP by inhibiting intracellular farnesyl py rophosphate (FPP) sy nthase, were required for maximal proliferation of $\mathrm{V} \gamma 9^{+} \mathrm{T}$ cells in SSc patients than in healthy controls, suggesting their dy sfunction in SSc; y et these cells still secreted 
factors that inhibited collagen production. ${ }^{19}$ Furthermore, less anti-fibrotic cytokines TNF- $\alpha$ and IFN- $\gamma$ were secreted in response to IPP in SSc. Indeed, reduction of procollagen secretion by fibroblasts cultured with supernatants of IPP-stimulatedPBMC was observed only in some SSc patients. ${ }^{19}$ On the other hand, $\gamma \delta$ T cell supernatants from patients induced more proliferation of fibroblasts than $\alpha \beta \mathrm{T}$ cell supernatants, and doubling of collagen synthesis in human skin fibroblasts maintained in supernatants of SSc-derived $\gamma \delta \mathrm{T}$ cells was observed, which was inhibited by anti-transforming growth factor-beta (TGF $\beta$ ) antibody and anti-basicfibroblast growth factor antibodies. ${ }^{20}$ Furthermore, $\mathrm{PB} \gamma \delta$ T cells of SSc patients expressed higher levels of CD16 and CD69 compared to healthy controls, and collagen gene 1 (COL1) A2 mRNA expression was significantly higher in fibroblasts co-cultured with $\gamma \delta$ T cells from SSc patients. ${ }^{21}$

\section{ANIMAL MODELS}

\section{Sy stemic Sclerosis}

The first indication that $\gamma \delta$ T cells participate in the pathogenesis of fibrotic conditions arose from research in UCD-20o chickens. These animals develop a hereditary connective tissue disease characterized by severe lymphocytic infiltration and fibrosis of skin and internal organs, a model of human progressive SSc. The skin infiltrating mononuclear cells in the deeper dermis weremainly TCR $\alpha \beta$ cells, whereas the perivascular area of the papillary dermis was enriched for TCR $\gamma \delta^{+}$ lymphocytes. 22

\section{Pulm onary Fibrosis Induced by a Non- Infectious Trigger}

\section{Bleom ycin model: evidence for involvement of $\gamma \delta$ T cells}

In the bleomycin (BLM) model of lung fibrosis induced by a single intratrachealinstillation of BLM, $>80 \%$ of the $\gamma \delta$ T cells in bronchoalveolar lavage (BAL) fluid expressed the E-cadherin binding $\alpha \mathrm{E} \beta 7$ integrin, at levels that were 2-3 times higher than on $\mathrm{CD}_{4}{ }^{+}$or $\mathrm{CD} 8+\mathrm{T}$ cells, suggesting a critical role for $\gamma \delta \mathrm{T}$ cells in the pathogenesis of BLM-induced lung fibrosis. ${ }^{23} \mathrm{After}$ exposure to BLM, but not to Schistosoma mansoni eggs, the interleukin (IL)-17A that was produced by $\mathrm{CD}_{4}^{+}$and $\gamma \delta \mathrm{T}$ cells induced significant neutrophilia and pulmonary fibrosis. In parallel, IL-17A and IL-1 $\beta$ were increased in theBAL fluid of patients with idiopathic pulmonary fibrosis
(IPF). ${ }^{24}$ Bleo mycin or IL-1 $\beta$-induced lung injury also led to increased expression of early IL-23p19and IL$17 \mathrm{~A}$ or IL-17 F. A very early IL-17 A and IL-17 F expression by ROR $\gamma \mathrm{t}(+) \gamma \delta \mathrm{T}$ cells could be demonstrated $24 \mathrm{~h}$ after BLM administration. In addition, IL-23p19 and IL-17A expressions or IL17 RA signaling were necessary for pulmonary TGF $\beta 1$ production, collagen deposition, and evolution to fibrosis. ${ }^{25}$ Likewise, in the surfactant protein $\mathrm{C} / \mathrm{TNF} \alpha$ (SP-C/TNF) transgenic mouse, where the $\mathrm{TNF}$ a transgene is overexpressed in type II pneumocytes, the absolute number of ly mphocytes recovered were approximately four times that in littermates, and included $\gamma \delta$ T cells and B1 cells. In these mice the pulmonary lymphocytic infiltration is followed by fibrotic changes including accumulation of fibroblasts and deposition of extracellular matrix. ${ }^{26}$ Moreover, when experimental animals were injected intravenously with saline or collagen (Col)V 10 days before intratracheal instillation of BLM, ColV-pretreated animals showed a significant reduction in lung inflammation compared withnontreated animals which associated with a lower proportion of $\gamma \delta$ and $\mathrm{CD}_{4}{ }^{+} \mathrm{T}$ cells. ${ }^{27}$ Afterlung injury by BLM, $\gamma \delta \mathrm{T}$ cells localized to the lung lesions and were the predominant source of IL-17 by flow cy tometry and real-time polymerase chain reaction (PCR). $\gamma \delta \mathrm{T}$ cell knockout (KO) mice showed a significant reduction in cellularinfiltration into the airways, reduced ex pression of IL-6 in the lung, a significant delay in epithelial repair, and increased inflammation and fibrosis. ${ }^{28}$ In another study, although $\gamma \delta$ T cell populations increased after BLM administration, pulmonary fibrosis was more severe in $\gamma \delta \mathrm{KO}$ mice, as measured by collagen deposition (hydroxyproline) and histopathological features. Furthermore, there was no evidence of resolution of the fibrotic response up to 45 days after BLM therapy. $\gamma \delta$ KO mice had decreased concentrations of IL-6, granulocyte colony-stimulating factor, chemokine C-X-C ligand (CXCL) 1 , and interferoninducible protein 10/CXCL10. Importantly, $\gamma \delta \mathrm{T}$ cells produced all four of these cytokines, and $\gamma \delta \mathrm{T}$ cells sorted from BLM-treated lung were sufficient to resolve fibrosis in $\gamma \delta$ KO mice. Ov erexpression of CXCL10 in the lung decreased the severity of fibrosis seen in the $\gamma \delta$ KO mice, and adoptive transfer of $\gamma \delta$ $\mathrm{T}$ cells from CXCL1 $\mathrm{O}(-/-)$ mice failed to reverse the severe fibrosis in $\gamma \delta$ KO mice. Thus, $\gamma \delta$ T cells promote resolution of fibrosis throughproduction of CXCL10.29 In addition, BLM-treated mice showed decreased levels of IL-22 in the lung, and IL-22producing $\gamma \delta$ T cells were also decreased significant- 
ly in the lungs and spleens. Blockade of IL-22deteriorated pulmonary fibrosis, and was associated with elevated $\alpha$-smooth muscle actin and ov eractivated Smad2. Thus, IL-22 produced by $\gamma \delta$ T cells may play a protective role in BLM-induced pulmonary fibrosis. ${ }^{30}$ Furthermore, BLM-inducedlung inflammation and subsequent fibrosis was ameliorated in osteopontin (OPN)-deficient mice, whereas OPN was expressed ubiquitously in the lung parenchymal and bone marrow-derived components. The TH1 7 differentiation of $\mathrm{CD}_{4}{ }^{+} \alpha \beta \mathrm{T}$ cells and IL-17producing $\gamma \delta$ T cells was reduced in OPN-deficient mice compared to wild-type mice, whereas TH1 differentiation and the percentage of IFN- $\gamma$-producing $\gamma \delta$ T cells increased. Thus, OPN expressed in both parenchymal and bone marrow cell components contributed to BLM-induced lung inflammationand fibrosis by affecting the ratio of pathogenic IL17 / protective IFN- $\gamma$ T cells. ${ }^{31}$

\section{Silicosis model}

Silicosis evolved over months after exposure of inbred mice to cristobalite silica with accumulation of ly mphocytes in alveolar spaces, in lung parenchymal lesions and nodules, and in enlarged bronchial-associated lymphoid tissues and thoracic lymph nodes. The lung ly mphocytes were predominantly $\mathrm{CD} 4{ }^{+} \mathrm{T}$ cells, with numerous $\mathrm{CD} 8{ }^{+} \mathrm{T}$ cells, natural killer cells, and $\gamma \delta$ T cells. ${ }^{32}$ In anotherstudy upregulation of IL-17 A was associated with the development of experimental silicosis, but was markedly reduced in athy mic, $\gamma \delta \mathrm{T}$ cell-deficient or $\mathrm{CD}_{4}{ }^{+} \mathrm{T}$ cell-depleted mice. $\gamma \delta \mathrm{T}$ ly mphocy tes and $\mathrm{CD}_{4}{ }^{+} \mathrm{T}$ cells, but not macrophages, neutrophils, NK cells, or CD8 T cells, purified from the lungs of silicotic mice, markedly expressed IL-17 A. Acute alveolitis induced by silica was IL-17A-dependent, but was dispensable for the late inflammatory and fibrotic lung responses. 33

\section{Melphalan model}

Exposure to melphalan, a nitrogen mustard, induced an early burst of the pro-inflammatory cy tokines IL-1 $\beta$, IL-6, and IL-23 in airways, followed by extensive infiltration of neutrophils in the lung tissue and airways. The acute phase was followed by a sustained ly mphocytic response that persisted for at least 14 days with resulting lung fibro sis. Engagement of T lymphocytes, particularly the $\gamma \delta$ T cell subset, was crucial both for the acutecytokine and neutrophil response and for the late-phase lung fibrosis as indicated by the lack of response in $\gamma \delta \mathrm{T}$ cell-deficient mice. 34

\section{Pulm onary Fibrosis Following a Bacterial} Infection

\section{Bacillus subtilis}

C57 BL/6 mice repeatedly exposed to Bacillus subtilis dev elop mononuclear infiltrates containing $\mathrm{V} \gamma 6^{+} / \mathrm{V} \delta 1^{+} \gamma \delta \mathrm{T}$ cells in the lung. In the absence of these, mice treated with B. subtilis had significantly increased collagen deposition in the lung, consistent with a regulatory role for $\mathrm{V} \gamma 6^{+} / \mathrm{V} \delta 1^{+} \gamma \delta \mathrm{T}$ cells. Exposing transgenic $\mathrm{V} \gamma 6^{+} / \mathrm{V} \delta 1^{+}$mice to $B$. subtilis decreased collagen content in the lung compared with wild-ty pe $\mathrm{C} 57 \mathrm{BL} / 6$ mice. Cy tokine analysis of lungs from wild-ty pe mice repeatedly exposed to $B$. subtilis demonstrated increased IL-17A concentrations. In the absence of IL-17 receptor signaling, IL$17 \mathrm{ra}(-/-)$ mice had delayed clearance of $B$. subtilis, with increased lung inflammation and fibrosis. Although IL-17A was predominantly expressed by $\mathrm{V} \gamma 6^{+} / \mathrm{V} \delta 1^{+} \gamma \delta \mathrm{T}$ cells, a compensatory increasein IL$17 \mathrm{~A}$ expression by $\mathrm{CD} 4^{+} \mathrm{T}$ cells was seen in the absence of $\gamma \delta$ T cells that resulted in similar levels of IL-17 A in the lungs of TCR $\delta(-/-)$ and wild-type C57 BL/ 6 mice, suggesting an important role for IL$17 \mathrm{~A}$-expressing $\gamma \delta$ or $\alpha \beta$ Tly mphocy tes in eliminating the micro-organism and preventing excessive inflammation and eventual lung fibrosis. 35 Likewise, in another study of this mouse model, $\gamma \delta$ T cells expanded in the lung and inhibited collagen deposition. A subset of these $\gamma \delta$ cells represents the predominant source of the TH1 7 cytokine IL-22 in this model. Preventing expression of IL-22 by mutating the aryl hydrocarbon receptor (AhR) - or inhibiting AhR signaling-accelerated lung fibrosis. Moreover, the presence of protective $\gamma \delta$ T cells and IL-22 diminished recruitment of $\mathrm{CD}_{4}{ }^{+} \mathrm{T}$ cells to lung. ${ }^{36}$ Finally, repeatedly exposing $\mathrm{C}_{57} \mathrm{BL} / 6$ mice to $B$. subtilis resulted in a 33 -fold increase in the number of CD4 $4^{+} \mathrm{T}$ cells and a 354 -fold increase in $\gamma \delta$ $\mathrm{T}$ cells in the lung. The $\gamma \delta \mathrm{T}$ cells consisted almost entirely of $\mathrm{V} \gamma 6^{+} / \mathrm{V} \delta 1^{+} \gamma \delta \mathrm{T}$ cells. Treatment of C57 BL/ 6 mice with heat-killed versus live B. subtilis resulted in a 2 -fold increase in the number of $\mathrm{CD}_{4}{ }^{+}$ $T$ cells in the lung but no expansion of $\gamma \delta$ T cells. In addition, mice treated with heat-killed B. subtilis developed significantly increased pulmonary fibrosis compared with mice treated with the live microorganism. Mice deficient in $\mathrm{V} \gamma \sigma^{+} / \mathrm{V} \delta 1^{+} \gamma \delta \mathrm{T}$ cells, when treated with $B$. subtilis, had a 231 -fold increase in lung $\mathrm{CD} 4+\mathrm{T}$ cells and significantly increased collagen deposition compared with wildty pe $\mathrm{C}_{57} \mathrm{BL} / 6$ mice, again consistent with an im- 
munoregulatory role for the $\mathrm{V} \gamma 6^{+} / \mathrm{V} \delta 1^{+} \gamma \delta \mathrm{T}$ cell subset. 35

\section{Tuberculosis}

The acute phase of pulmonary tuberculosis induced in BALB/c mice by the intratracheal instillation of the live virulent strain $\mathrm{H}-37 \mathrm{Rv}$ was characterizedby an inflammatory infiltrate in the alv eolar capillary interstitium, blood vessel, and bronchial wall with formation of granulomas from 1 to 28 days after infection and a predominance of $\mathrm{TH} 1$ cells. The chronic phase was characterized by pneumonia, focal necrosis, and fibrosis. $\gamma \delta$ T ly mphocytes were involved both at the beginning (3 days) and the later stages of the infection. 37 In bovine tuberculosis, there was an increase in the expression of TGF $\beta$, and of ty pe I procollagen in advanced stage granulomas. As the granulomas advanced, there was a steady increase in the number of $\mathrm{CD}^{2} 8^{+}$cells and $\gamma \delta \mathrm{T}$ cells. 38

\section{Liver Fibrosis Induced by a Non-Infectious Trigger}

\section{Carbon tetrachloride model}

Increased IL-17A production was mainly detectedin hepatic $\gamma \delta$ T cells in wild-ty pe mice. Liver fibrosis and IL-17 A production by $\gamma \delta \mathrm{T}$ cells were both significantly attenuated in toll-like receptor (TLR)-3 KO mice compared with wild-type mice. Interleukin-17A-producing $\gamma \delta$ T cells were in close contact with activated hepatic stellate cells (HSCs), suggesting a role for HSCs in IL-17A production by $\gamma \delta$ T cells. Interleukin-17A production by $\gamma \delta$ T cells was substantially increased upon co-culturing with exosome-treated wild-type HSCs or conditioned medium from TLR3-activated wild-type HSCs. Tolllike receptor-3 deficiency in HSCs contributed to decreased IL-17A production by $\gamma \delta \mathrm{T}$ cells, as well as liver fibrosis. Thus, in liver injury, the exosomemediated activation of TLR 3 in HSCs exacerbates liver fibrosis by enhancing IL-17A production by $\gamma \delta$ T cells, which might be associated with HSC stimulation by unknown self-TLR3 ligands fromdamaged hepatocytes. 39 Chemokine receptor 6 (CCR6) and chemokine ligand (CCL) 20 expression were intrahepatically upregulated in patients with chronic liver diseases compared to control liver, with periportal accumulation of CCR6(+) mononuclear cells and CCL2O induction by hepatic parenchymal cells. In murine livers CCR6 was expressed by macrophages, $\mathrm{CD}_{4}^{+}$, and $\gamma \delta$ T cells and upregulated in fibrosis, whereas CCL2O was induced by injury in primary hepatocytes. In the carbon tetrachloride $\left(\mathrm{CCl}_{4}\right)$ and methionine-choline-deficient dietinduced murine models of chronic liver injury, Ccr6(-/-) mice developed more severefibrosis with enhanced immune cell infiltration than wild-type mice, and CCR6 was required by IL-17- and IL-22expressing $\gamma \delta$ T cells for accumulation in injured liver. Adoptive transfer of wild-type $\gamma \delta$, but not $\mathrm{CD}_{4}{ }^{+} \mathrm{T}$ cells, into Ccr6(-/-) mice reduced hepatic inflammation and fibrosis in chronic injury to wildtype level. The anti-inflammatory function of hepatic $\gamma \delta$ T cells was independent of IL-17, whereas $\gamma \delta \mathrm{T}$ cells co-localized with HSCs in vivo and promoted apoptosis of primary murine HSCs in a cell-cell contact-dependent manner, involving Fasligand (CD95 L). 40

\section{Liver Fibrosis Induced by an Infectious Agent}

\section{Fasciola hepatica (fluke)}

Ten days after primary infection with Fasciola hepatica (fluke), portal tract areas surrounding migratory tunnels were infiltrated with T cells and $\mathrm{B}$ cells. Micro-abscesses were distributed sporadically in the liver parenchyma, and young flukes were observed in the liver tissue free from inflammatory cells. Chronic primary infections were characterized by perilobular fibrosis and a predominance of CD8 ${ }^{+}$ and $\gamma \delta$ T cells. ${ }^{4}$

\section{Cryptosporidium parvum}

Inoculation of mice deficient in $\alpha \beta$ and $\gamma \delta$ T cells with Cryptosporidium parvum resultedin persistent infection and severe inflammatory boweldisease-like lesions contrasting with neonatal immunocompetent strains of mice which results in a transient, noninflammatory enteric infection. Glandular hyperplasia, abscess formation, and extensivefibrosis of the lamina propria and extensive hepatic periportal fibrosis were noted in persistently infected mice, which were not observed in mice deficient only in $\alpha \beta$ T cells. 42

\section{Rotavirus}

Livers from rhesus rotavirus-infected mice that develop biliary atresia (BA) had 7 -fold more IL-17 messenger RNA than control mice $(P=0.02) . \gamma \delta \mathrm{T}$ cells were the exclusive source of IL-17. Mice that were developing BA and given antibodies against IL17 had lower levels ofliver inflammation. Likewise, liver tissues from patients with BA had 4.6-fold higher levels of IL-17 messenger RNA than control liver tissues $(P=0.02) .43$ 
Table 1. Models and Mechanisms of Pro- and Anti-fibrotic Effects of $\gamma \delta$ T Cells.

\begin{tabular}{|c|c|c|c|c|}
\hline Model & $\begin{array}{l}\text { Pro- } \\
\text { fibrotic }\end{array}$ & $\begin{array}{l}\text { Anti- } \\
\text { fibrotic }\end{array}$ & Mechanism & Ref \\
\hline $\begin{array}{l}\text { BLM-induced murine lung } \\
\text { fibrosis }\end{array}$ & + & & IL-17 production by $\gamma \delta \mathrm{T}$ and TH17 cells & 25 \\
\hline $\begin{array}{l}\text { BLM-induced murine lung } \\
\text { fibrosis }\end{array}$ & & + & Production of CXCL10 by $\gamma \delta T$ cells & 29 \\
\hline $\begin{array}{l}\text { BLM-induced murine lung } \\
\text { fibrosis }\end{array}$ & & + & IL-22 produced by $\gamma \delta$ T cells & 30 \\
\hline $\begin{array}{l}\text { BLM-induced lung fibrosis in } \\
\text { osteopontin-deficient mice }\end{array}$ & & + & IFN- $\gamma$-producing $\gamma \delta$ T cells & 31 \\
\hline $\begin{array}{l}\text { Melphalan-induced murine lung } \\
\text { fibrosis }\end{array}$ & + & & $\begin{array}{l}\text { Induction of pro-inflammatory } \\
\text { cytokines, e.g. IL- } 6 \text { and IL-1B }\end{array}$ & 34 \\
\hline $\begin{array}{l}\text { Bacillus subtilis-induced murine } \\
\text { lung fibrosis }\end{array}$ & & + & $\begin{array}{l}\text { IL-17A-expressing } \gamma \delta \mathrm{T} \text { cells } \\
\text { involvement in removal of offending } \\
\text { organism }\end{array}$ & 35 \\
\hline $\begin{array}{l}\text { Bacillus subtilis-induced murine } \\
\text { lung fibrosis }\end{array}$ & & + & Production of IL-22 by $ү \delta$ T cells & 36 \\
\hline $\begin{array}{l}\text { Bacillus subtilis-induced murine } \\
\text { lung fibrosis }\end{array}$ & & + & $\begin{array}{l}\text { Immunoregulatory role of } V_{\gamma} 6 / \mathrm{V} \delta 1(+) \\
\gamma \delta T \text { cell subset }\end{array}$ & 35 \\
\hline $\begin{array}{l}\text { Carbon tetrachloride }\left(\mathrm{CCl}_{4}\right) \\
\text { murine model of liver fibrosis }\end{array}$ & + & & $\begin{array}{l}\text { TLR3 activation of IL-17 secretion by } \gamma \delta \\
\text { T cells }\end{array}$ & 39 \\
\hline $\begin{array}{l}\text { Carbon tetrachloride }\left(\mathrm{CCl}_{4}\right) \\
\text { murine model of liver fibrosis }\end{array}$ & & + & $\begin{array}{l}\text { Promotion of apoptosis of hepatic } \\
\text { stellate cells by } \gamma \delta \text { T cells }\end{array}$ & 40 \\
\hline $\begin{array}{l}\text { Cryptosporidium parvum } \\
\text { infection-induced murine liver } \\
\text { periportal fibrosis }\end{array}$ & + & & No mechanism presented & 42 \\
\hline $\begin{array}{l}\text { Rotavirus infection inducing } \\
\text { murine biliary atresia }\end{array}$ & + & & IL-17 production by $ү \delta$ T cells & 43 \\
\hline $\begin{array}{l}\text { Schistosoma japonicum-induced } \\
\text { murine liver fibrosis }\end{array}$ & + & & IL-17 production by $ү \delta$ T cells & 44 \\
\hline $\begin{array}{l}\text { In vitro experiments using } \\
\text { human cells }\end{array}$ & & + & $\begin{array}{l}\text { Cell contact-dependent apoptosis of } \\
\text { fibroblasts and reduction of collagen } \\
\text { secretion byproducts of } \mathrm{V} \gamma 9 \mathrm{~V} \delta 2+\mathrm{T} \text { cells }\end{array}$ & 18,19 \\
\hline In vitro human experiments & + & & $\begin{array}{l}\text { Increased fibroblast proliferation and } \\
\text { collagen production by supernatants of } \\
\gamma \delta \text { T cells of systemic sclerosis patients }\end{array}$ & 20,21 \\
\hline
\end{tabular}

BLM, Bleomycin; CXCL10, C-X-C motif chemokine 10; IL, interleukin; TH, T helper; TL,toll-like.

\section{Schistosomajaponicum}

In $\mathrm{C}_{57} \mathrm{BL} / 6$ mice infected with $S$. japonicum expression and release of IL-17 was significantly higher in hepatic lymphocytes from infected mice. Interleukin-17 was induced in all $\mathrm{CD}_{4}{ }^{+}$and NK cells by PMA and ionomycin, but $\gamma \delta \mathrm{T}$ lymphocytes exhibited the largest increase. Reducing IL-17 activity using anti-IL-17 A antibodies decreased infiltration of inflammatory cells and collagen deposition in the livers of infected $\mathrm{C} 57 \mathrm{BL} / 6$ mice. 44

\section{CONCLUSION}

In summary, the data clearly indicate the involvement of $\gamma \delta$ T cells in major human fibrotic diseases, as well as in models of post-inflammatory fibrosisin animals. The experimental models, however, suggest 


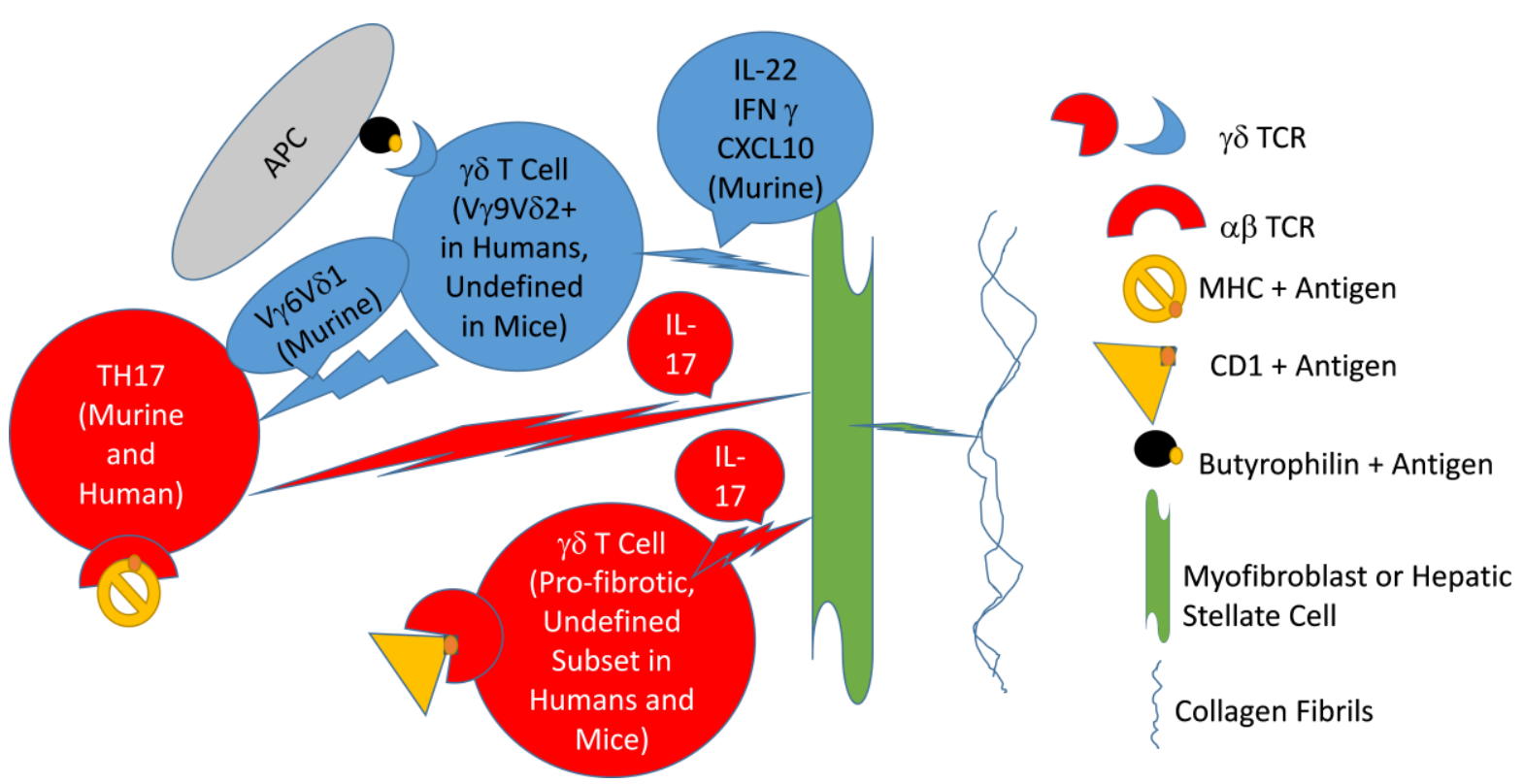

Figure 1. Hypothetical Model of $\gamma \delta \mathrm{T}$ Cell Involvement in Fibrosis.

A hypothetic al model is depicted of how two types of $\gamma \delta$ T cells, a T helper (TH) cell antigen-presenting cell (APC) and a myofibroblast, are involved in induction collagen secretion. The APCs are depicted presenting a peptidic antigen in $\mathrm{MHC}$ to the TH17 aB T cell receptor, or a lipid antigen to a $\gamma \delta \mathrm{T}$ cell via a CD1 molecule, eliciting release of IL-17 that activates the myofibroblast to secrete collagen. Other $\gamma \delta$ T cells, of the phosphoantigen -recognizing variety in humans, or, in the murine system, a subset secreting IL-22 and CXCL10, may become activated by other antigens presented by butyrophilins, to exert anti-fibrotic activity by inducing apoptosis of the myofibroblast or hepatic stellate cells, or by suppressing TH17 cells. Red depicts pro- and blue anti-fibrotic functions.

dual involvement: a role in induction of inflammation that can lead to fibrosis by IL-17-secreting $\gamma \delta$ $\mathrm{T}$ cells, contrasting with a role in prevention of fibrosis related to $\gamma \delta \mathrm{T}$ cells that mediate either killing of cells responsible for secreting the extracellular matrix, or by subsets of these cells that secrete either matrix-degrading enzymes, IL-22, CXCL1 o, or IFNy (Table 1, Figure 1, and Workalemahu et al.45). Much further study is required to elucidate the mechanisms that control pro- and antifibrotic effects of $\gamma \delta$ T cells in human disease, since manipulation of these responses might enable prevention or alleviation of severe human fibrotic diseases.

\section{REFERENCES}

1. Wy nn TA, Ramalingam TR. Mechanisms of fibrosis: ther apeutic translation for fibrotic disease. Nat Med 2012;18:1028-40. Full Text

2. Bank I, DePinho RA, Brenner MB, Cassimeris J, Alt $\mathrm{FW}$, Chess L. A functional T3 molecule associated with a novel heterodimer on thesu rface of immature human thymocytes. Nature 1986;322:179-81. Full $\underline{\text { Text }}$

3. Brenner MB, McLean J, Dialynas DP, et al. Identification of a putative second T-cell receptor. Nature 1986;322:145-9. Full Text

4. Vantou rout P, Hayday A. Six -of-the-best: unique contributions of gammadeltat cells to immunology. Nat Rev Immunol 2013;13:88-100. Full Text

5. Hay day A, Vantourout P. A long-playing CD about the gammadelta TCR repertoire. Immunity 2013; 39:994-6. Full Text

6. Gober HJ, Kistowska M, Angman L, Jeno P, Mori L, De Libero G. Human T cell receptor gammadelta cells recognize endogenous m evalonate metabolites in tum or cells. J Exp Med 2 003;197:163-8. Full Text

7. VavassoriS, Kumar A, Wan GS, et al. Butyrophilin 3 A1 binds phosphorylated antigens and stimulates hu man gammadelta T cells. Nat Im munol 2013;14: 908-16. Full Text

8. Harly C, PeigneCM, Scotet E. Molecules and mechanisms implicated in the peculiar antigenic activation 
process of human VgammagVdelta2 T cells. Front Immunol 2015;5:657. Full Text

9. Sandstrom A, Scharf L, McRaeG, Hawk AJ, Meredith SC, Adams EJ. $\gamma \delta$ T cell receptors recognize the nonclassical major histocompatibility com plex (MHC) molecule T22 via conserved anchor residues in a MHC peptide-like fashion. J Biol Chem 2012;287: 6035-43. Full Text

10. Luoma AM, Castro CD, May assi T, et al. Cry stal structure of $\mathrm{V} \delta 1 \mathrm{~T}$ cell receptor in complex with $\mathrm{CD} 1 \mathrm{~d}-$ sulfatide shows MHC-like recognition of a self-lipid by human $\gamma \delta$ T cells. Im munity 2013;39:1032-42. Full Text

11. Wang H, Henry O, Distefano MD, et al. Butyrophilin 3 A1 plays an essential role in prenyl pyrophosphate stimulation of human $\mathrm{V}_{2} 2 \mathrm{~V} \delta 2 \mathrm{~T}$ cells. J Im munol 2013;191:1029-42. Full Text

12. Harly C, Guillaume Y, Nedellec S, et al. Key implication of CD277/butyrophilin-3 (BTN3A) in cellular stress sensing by a major hum an $\gamma \delta \mathrm{T}$-cell subset. Blood 2012;120:2269-79. Full Text

13. Di Marco Barros R, Roberts NA, Dart RJ, et al. Epithelia u se buty rophilin-like molecules to shape organ-specific $\gamma \delta \mathrm{T}$ cell compartments. Cell 2016 ; 167:203-18 e17.

14. Bank I, Marcu-Malina V. Quantitative peripheral blood perturbations of $\gamma \delta$ T cells in human disease and their clinical implications. Clin Rev Allergy Immunol 2014;47:311-33. Full Text

15. Giacom elli R, Matucci-Cerinic M, Cipriani P, et al. Circulating Vdelta1 $+\mathrm{T}$ cells are activated and accumulate in the skin of systemic sclerosis patients. Arthritis Rheum 1998;41:327-34. Full Text

16. White B, Yurovsky VV. Oligoclonal expansion of V delta 1+ gamma/delta T-cells in sy stemic sclerosis patients. Ann N Y Acad Sci 1995;756:382-91. Full $\underline{\text { Text }}$

17. Ercole LP, Malvezzi M, Boaretti AC, Utiy am a SR, Rachid A. Analysis of lymphocyte subpopulations in sy stemic sclerosis. J Investig Allergol Clin Im munol 2003;13:87-93.

18. Bendersky A, Marcu-Malina V, Berkun Y, et al. Cellular interactions of sy novial fluid gammadelta $T$ cells in juv enile idiopathic arthritis. J Im munol 2012;188:4349-59. Full Text

19. Markovits N, Bendersky A, Loebstein R, Brusel M, Kessler E, Bank I. Anti-fibrotic characteristics of $\mathrm{V} \gamma 9+\gamma \delta \mathrm{T}$ cells in sy stemic sclerosis. Clin Exp Rheumatol 2016 Feb 9. [Epub ahead of print].

20. Ohtsuka T. Effect of gammadelta T cell su pernatant on hum an skin fibroblast proliferation and collagen production - possible role of transforming growth factor-beta and basic fibroblast growth factor. Int $\mathrm{J}$ Dermatol 2008;47:1135-40. Full Text

21. Ueda-Hay akawa I, Hasegawa M, Hamaguchi Y, Takehara K, Fujimoto M. Circulating $\gamma / \delta$ T cells in sy stemic sclerosis exhibit activated phenoty pe and enhance gene expression of proalpha2(I) collagen of fibroblasts. J Dermatol Sci 2013;69:54-60. Full Text

22. Gruschwitz MS, Moormann S, Kromer G, et al. Phen otypic analy sis of skin infiltrates in comparison with peripheral blood lymphocytes, spleen cells and thymocytes in early avian scleroderma.J Autoimmun 1991;4:57 -93. Full Text

23. Braun RK, Sterner-Kock A, Kilshaw PJ, Ferrick DA, Giri SN. Integrin alpha E beta7 expression on BAL CD4 +, CD8+, and gamma delta T-cells in bleomycininduced lung fibrosis in mouse. Eur Respir J 1996;9: 673-9. Full Text

24. Wilson MS, Madala SK, Ramalingam TR, et al. Bleom y cin and IL-1 beta-mediated pulmonary fibrosis is IL-1 7 A dependent. J Exp Med 2 010;207:535-52. Full Text

25. Gasse P, Riteau N, Vacher R, et al. IL-1 and IL-23 mediate early IL-17 A production in pulmonary inflammation leading to late fibrosis. PLoS One $2011 ; 6: \mathrm{e} 23185$. Full Text

26. Nakama K, Miyazaki Y, Nasu M. Immunophen otyping of lymphocy tes in the lung interstitium and expression of osteopontin and interleukin-2 m RNAs in two different murine models of pulmonary fibrosis. Exp Lung Res 1998;24:57 -70. Full Text

27. Braun RK, Martin A, Shah S, et al. Inhibition of bleomycin-induced pulmon ary fibrosis through pretreatment with collagen type V. J Heart Lung Transplant 2010;29:873-80. Full Text

28. Braun RK, Ferrick C, Neubauer P, et al. IL-17 producing gammadelta $\mathrm{T}$ cells are required for a controlled inflammatory response after bleomycin induced lung injury. Inflammation 2008;31:167-79. Full Text

29. Pociask DA, Chen K, Choi SM, Oury TD, Steele C, Kolls JK. $\gamma \delta$ T cells attenuate bleomy cin-induced fibrosis through the production of CXCL1 O. Am J Pathol 2011;178:1167-76. Full Text

30. Liang M, Wang J, Chu H, et al. Interleukin-22 inhibits bleomy cin-induced pulm onary fibrosis. Mediators Inflamm 2013;2013:2 09179. Full Text

31. Oh K, Seo MW, Kim YW, Lee DS. Osteopontin potentiates pulmonary inflammation andfibrosis by modulating IL-1 $7 / \mathrm{IFN}-\gamma$-secreting T-cell ratios in bleom y cin-treated mice. Immune Netw 2015;15:1429. Full Text 
32. Dav is GS, Holmes CE, Pfeiffer LM, Hem enway DR. Ly m phocytes, lymphokines, and silicosis. J Environ Pathol Toxicol Oncol 2 001;20(Suppl 1):53-65. Full Text

33. Lo Re S, Dumoutier L, Couillin I, et al. IL-1 7 A-producing gammadelta T and Th17lymphocytes mediate lung inflammation but not fibrosis in experimental silicosis. J Im munol2010;184:6367 -77 . Full Text

34. Ekstrand-Hammarstrom B, Wigenstam E, Bucht A. In halation of alkylating mustard causes long-term $\mathrm{T}$ cell-dependent inflammation in airways and growth of connectivetissue. Toxicology 2011;280:88-97. Full $\underline{\text { Text }}$

35. Sim onian PL, Roark CL, Wehrmann F, et al. IL-17Aexpressing T cells a re essential for bacterial clearance in a murine model of hypersensitivity pneumonitis. $\mathrm{J}$ Immunol 2009;182:6540-9. Full Text

36. Simonian PL, Wehrmann F, Roark CL, Born WK, O'Brien RL, Fonten ot AP. $\gamma \delta$ T cells protect against lung fibrosis via IL-2 2. J Exp Med 2010;207:223953. Full Text

37. Hernandez-Pando R, Orozcoe H, Sampieri A, et al. Cor relation between the kinetics of Th1, Th2 cells and pathology in a murine model of experim ental pulm on ary tuberculosis. Im mun ology 1996;89:26-33.

38. Wangoo A, Johnson L, Gough J, et al. Adv anced granulomatous lesions in My cobacterium bovisinfected cattle are associated with increased expression of ty pe I procollagen, gammadelta $(\mathrm{WC} 1+) \mathrm{T}$ cells and CD 68+ cells. JComp Pathol 2005;133:22334. Full Text

39. Kim DS, Lee KY, Yang WI, Han SJ, Hwang EH. Gam ma/delta T lymphocytes in the BCG granulo- matous lesions. Yonsei Med J 1996;37:319-24. Full $\underline{\text { Text }}$

40. Hammerich L, Bangen JM, Govaere O, et al. Chem okin ereceptor CCR6-dependent accumulation of $\gamma \delta \mathrm{T}$ cells in injuredliver r estricts hepatic inflam$\mathrm{m}$ ation and fibrosis. Hepatology $2014 ; 59: 630-42$. Full Text

41. Meeusen E, Lee CS, Rickard MD, Brandon MR. Cellular responses during liver fluke infection in sheep and its evasion by the parasite. Parasite Im munol 1995;17:37-45. Full Text

42. Waters WR, Wannemuehler MJ, Sacco RE, et al. Cry ptosporidium parvum-induced inflam matory bowel disease of TCR-beta-xTCR-delta-deficient mice. J Parasitol 1999;85:1100-5. Full Text

43. Klem ann C, Schroder A, Dreier A, et al. Interleukin 17 , produced by $\gamma \delta \mathrm{T}$ cells, contributes to hepatic inflammation in a mou semodel of biliary atresia and is increased in livers of patients. Gastroenterology 2016;150:229-41 e5.

44. Chen D, Luo X, Xie H, Gao Z, Fang H, Huang J. Characteristics of IL-1 7 induction by Schistosom a japonicum infection in $\mathrm{C}_{57} \mathrm{BL} / 6$ mouse liver. Immunology 2013;139:523-32. Full Text

45. Workalemahu G, Foerster M, Kroegel C. Expression of metalloproteinase-7 (matrilysin) in human blood and bronchoalveolar gamma/deltaT-lymph ocy tes. Selective upregulation by the soluble non-peptidic mycobacterial phosphoantigen (isopentenyl py r ophosphate). J Cell Physiol 2006;207:67-74. Full Text 